\title{
Reproductive aspects of Sphoeroides annulatus (Jenyns, 1842) (Tetraodontiformes, Tetraodontidae) inhabiting the Mazatlan coast, Sinaloa, Mexico
}

\author{
Aspectos reproductivos de Sphoeroides annulatus (Jenyns, 1842) (Tetraodontiformes, \\ Tetraodontidae) en la costa de Mazatlán, Sinaloa, México \\ Rebeca Sánchez-Cárdenas ${ }^{1}$, Bertha P. Ceballos-Vázquez¹, Marcial Arellano-Martínez ${ }^{1}$, \\ María C. Valdez-Pineda ${ }^{2}$ and Ramón E. Morán-Angulo ${ }^{2}$ \\ ${ }^{1}$ Centro Interdisciplinario de Ciencias Marinas. Instituto Politécnico Nacional. Av. Instituto Politécnico Nacional s/n, \\ Playa Palo de Santa Rita, Apartado Postal 592, La Paz, B.C.S., 23096, México \\ ${ }^{2}$ Facultad de Ciencias del Mar. Universidad Autónoma de Sinaloa. Paseo Claussen s/n. Apdo. Postal 610, \\ Mazatlán, Sinaloa, 82000, México \\ bceballo@ipn.mx
}

Resumen.- La muestra de Sphoeroides annulatus capturada en la costa de Mazatlán, Sinaloa, México fue predominantemente de adultos, como resultado de una aparente distribución diferencial por talla/edad de la especie. La proporción sexual fue 1:1. Las hembras presentaron un crecimiento alométrico y los machos, isométrico. De acuerdo con el análisis morfocromático de las gónadas, la época de reproducción es en abril-mayo y octubre-noviembre, aunque los machos presentan madurez durante periodos más amplios. El IGS sí es un buen indicador de la época de reproducción de $S$. annulatus, mientras que el $\mathrm{Kn}$ muestra una tendencia a disminuir durante el periodo de reproducción.

Palabras clave: Reproducción, proporción de sexos, índice gonadosomático, botete

\section{Introduction}

Sphoeroides annulatus is a widely distributed species, ranging from southern California, USA, down to Peru, including the Gulf of California and the Galapagos Islands; this fish penetrates to coastal lagoons, and its permanence in these environments is seemingly related to size and age (Castro-Aguirre et al. 1999), using them as nursery areas (Álvarez-Cadena et al. 1987). As adult, this fish migrates to the neritic zone, inhabiting muddy and sandy bottoms (Castro-Aguirre et al. 1999), preferentially in the shallow platform between 20 and $40 \mathrm{~m}$, as well as in protected areas within bays (Mariscal-Romero et al. 1998). Despite its availability in Mexican littorals, its exploitation for human consumption has taken place just recently, given that tetraodontids are widely known for being a poisonous food due to the tetrodoxin content (Ahasan et al. 2004). However, they are regarded as a gastronomic delicacy in Japan (Ghosh et al. 2005).
In the Mazatlan coast, Mexico, the commercial exploitation of S. annulatus started in 1972 (OcampoPeraza 1983), where according to elderly fishermen, Japanese immigrants taught local fishermen that the poison is contained in guts, along with the proper techniques for removing them from muscles. Recent investigations have revealed that in $S$. annulatus tetrodoxin is absent in adult muscle, while it is present in very low concentrations in guts and mucus (Ochoa et al. 2006). Today, it is one of the fish species with higher commercial value (\$10 USD/kg), and its market demand is on the rise, to the extent that it has raised interest in cultivating it (Abdo de la Parra \& Duncan 2002). Despite the growing importance of $S$. annulatus as a fishing and culture resource, knowledge on the biology of wild populations is scarce and scattered. For this reason, there are no biological elements to either support an adequate fishing management or set the biological bases for cultivation. Thus, this investigation aims to determine some basic aspects about the reproductive biology of $S$. annulatus. 


\section{Material and methods}

Random weekly samplings were conducted from January 2004 to January 2005, obtained from the Playa Norte local fishing catches, which operate throughout the Mazatlan city coast, Sinaloa, Mexico $\left(23.17^{\circ} \mathrm{N}-\right.$ $106.40^{\circ} \mathrm{W}$ to $23.32^{\circ} \mathrm{N}-106.50^{\circ} \mathrm{W}$ ). For each specimen the total length $\left(\mathrm{L}_{\mathrm{t}}\right)$ and total mass $\left(\mathrm{M}_{\mathrm{t}}\right)$ were recorded. Sex was determined through the direct observation of gonads, and gonad mass was recorded. The annual and monthly sex ratios were calculated, as well as according to size intervals. Ratios were compared with the hypothetical 1:1 value through a $\chi^{2}$ test (Zar 1996). Sizes between the two sexes were compared using the Kolmogorov-Smirnov non-parametric test (Zar 1996). The potential $\mathrm{L}_{\mathrm{t}}-\mathrm{M}_{\mathrm{t}}$ relationship was determined for the total sample and by sex, using in the last case the same size interval for females and males. To determine the type of growth in $S$. annulatus, the slope obtained was compared to the hypothetical value of 3 (isometry) through the Student's $t$-test (Zar 1996).

In order to establish the degree of gonadal development two methods were applied, a qualitative and a quantitative one. The quantitative method consisted of calculating the gonadosomatic index (GSI) (De Vlaming et al. 1982) and the relative condition factor (Kn) (Le Cren 1951).

The monthly variations in Kn and GSI by sex and according to the gonadal development phase were analyzed through a one-way analysis of variance (ANOVA), followed by an a posteriori Newman-Keuls multiple comparison test; given that numbers were percent values, they were subjected to a natural logarithmic transformation prior to the test (Zar 1996). Last, a Pearson's correlation analysis between Kn and GSI was carried out for each sex, and the correlation coefficient was compared with a hypothetical value of zero through a Student's $t$-test (Zar 1996).

The qualitative method to determine the degree of ripening consisted in establishing a morpho-chromatic scale for $S$. annulatus males and females, based on the morpho-chromatic ripening scale for fishes proposed by Agger et al. (1974) and applying our own observations. Hence, the reproductive cycle was described through the ripening phases' monthly frequencies.

\section{Results}

A total sample of 497 Sphoeroides annulatus specimens was obtained, comprising 227 females and 270 males. The overall sex ratio was $1 \mathrm{M}: 0.84 \mathrm{~F}$, with no significant differences relative to the hypothetical 1M:1F ratio $\left(\chi^{2}=3.5, P=0.06\right)$. However, when the sex ratio was analyzed by month and size, significantly more males than females were found in June (1M:0.48F) $\left(\chi^{2}=4.2, P=0.04\right)$, and in the $28-32 \mathrm{~cm} \mathrm{~L}_{\mathrm{t}}$ (1M:0.7F) $\left(\chi^{2}=5.0, P=0.03\right)$ and $600-800 \mathrm{~g} \mathrm{M}_{\mathrm{t}}$ $(1 \mathrm{M}: 0.65 \mathrm{~F})\left(\chi^{2}=7.1, P=0.01\right)$.

The ranges of size distribution of $S$. annulatus specimens were 20.5 to $44 \mathrm{~cm} \mathrm{~L}_{\mathrm{t}}\left(\right.$ mean $\left.=29.06 \mathrm{~cm} \mathrm{~L}_{\mathrm{t}}\right)$ and 200 to $2200 \mathrm{~g} \mathrm{M}_{\mathrm{t}}$ (mean =678.57 $\mathrm{g} \mathrm{M}_{\mathrm{t}}$ ). The modal total length was in the size interval of $28-30 \mathrm{~cm} \mathrm{~L}_{t}$ (27.97\%), and the modal total mass corresponded to the

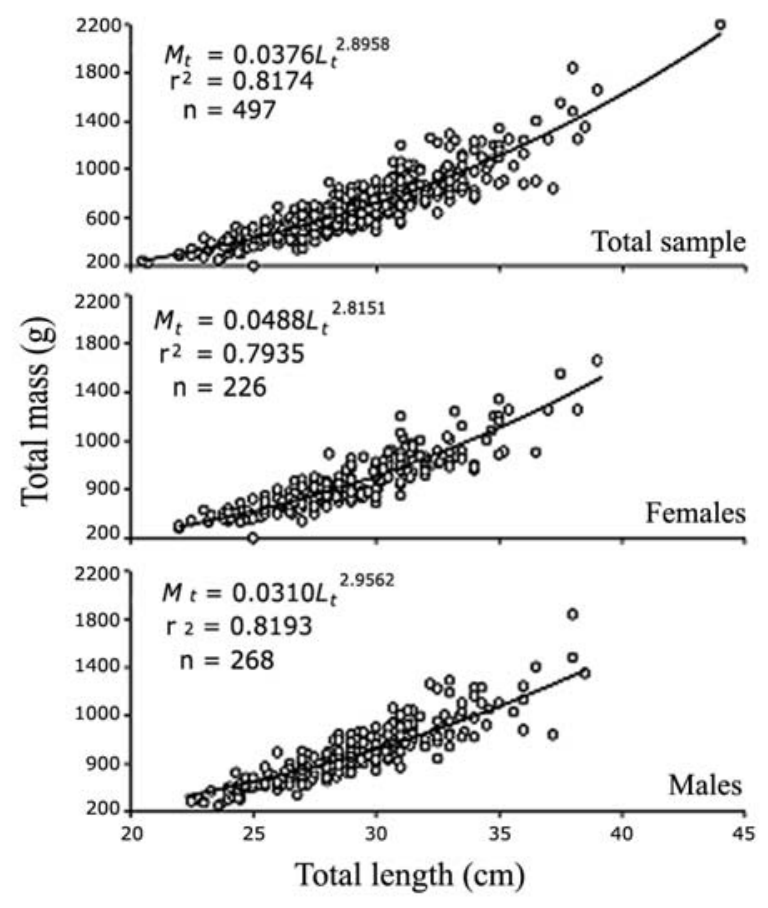

Figure 1

Total length-total mass relationship for total sample, males, and females $S$. annulatus

Correlación longitud total-masa total para la muestra total, machos y hembras de $S$. annulatus 
600-800 g $M_{t}$ interval (30.99\%). When sizes were compared between females and males no significant differences were obtained $\left(\mathrm{L}_{\mathrm{t}}\right.$; Dmax $=0.04, P=0.10$ and $\mathrm{M}_{\mathrm{t}} ;$ Dmax $=0.03, P>0.10$ ).

The length-mass relationship for the total sample of S. annulatus and by sex is shown in Fig 1. S. annulatus was found to display a negative allometric growth ( $t=1.69 ; P=0.05, \mathrm{n}=497$ ) when the total sample was considered (slope $=2.90$ ). However, when this analysis is conducted by sex, males might display an isometric growth, since the slope $(b=2.96)$ is not significantly different from the isometric value $(t=0.51, P=0.30$, $n=268)$. By contrast, a negative allometric growth was confirmed for females $(\mathrm{b}=2.82, t=1.93, P=0.03$, $n=226)$.

\section{Reproductive cycle}

The ovary development was macroscopically characterized into five phases: resting, early developing, late developing, ripe and spent, which are described in Table 1. Four phases were identified in males: resting, developing, ripe and spent (Table 2). Based on the reproductive cycle (Fig. 2), S. annulatus showed two reproductive periods throughout the year. The first and most important one took place in the spring-summer, from April to August. The second period, of a lower intensity, occurred in OctoberNovember.

Table 1

Developmental morpho-chromatic stages in the ovary of $S$. annulatus

Fases morfocromáticas de desarrollo en el ovario de $S$. annulatus

\begin{tabular}{ll}
\hline \multicolumn{1}{c}{ Stage } & \multicolumn{1}{c}{ Description } \\
\hline Resting & Small and turgent ovaries, with a translucent red color \\
Early developing & Enlarged and flaccid ovaries, with a light pink color \\
Late developing & $\begin{array}{l}\text { Larger and turgent ovaries, with a cream and yellowish color. Small oocytes can } \\
\text { be quite observed. With evident vascularization }\end{array}$ \\
Ripe & $\begin{array}{l}\text { Large, turgent and totally filled ovaries, with cream color. Large oocytes can be } \\
\text { easily observed. Highly vascularized but less evident }\end{array}$ \\
Spent & Flaccid and empty ovaries, with a pink brownish color \\
\hline
\end{tabular}

Table 2

Developmental morpho-chromatic stages in the testis of $S$. annulatus

Fases morfocromáticas de desarrollo en el testículo de S. annulatus

\begin{tabular}{|c|c|}
\hline Stage & Description \\
\hline Resting & Small and compact testis, with a cream color. It may present light red tonalities \\
\hline Developing & $\begin{array}{l}\text { Larger testis, firm to touch, with a pale cream color. With more evident light red tonalities. } \\
\text { Vascularization can be quite observed }\end{array}$ \\
\hline Ripe & $\begin{array}{l}\text { Robust and firm testis, with a cream color. Present a white zone in the inner part of lobes, which } \\
\text { corresponds to the collector tubule. Applying a light pressure the sperm is ejected }\end{array}$ \\
\hline Spent & Flaccid and empty testis, with a cream brownish color \\
\hline
\end{tabular}




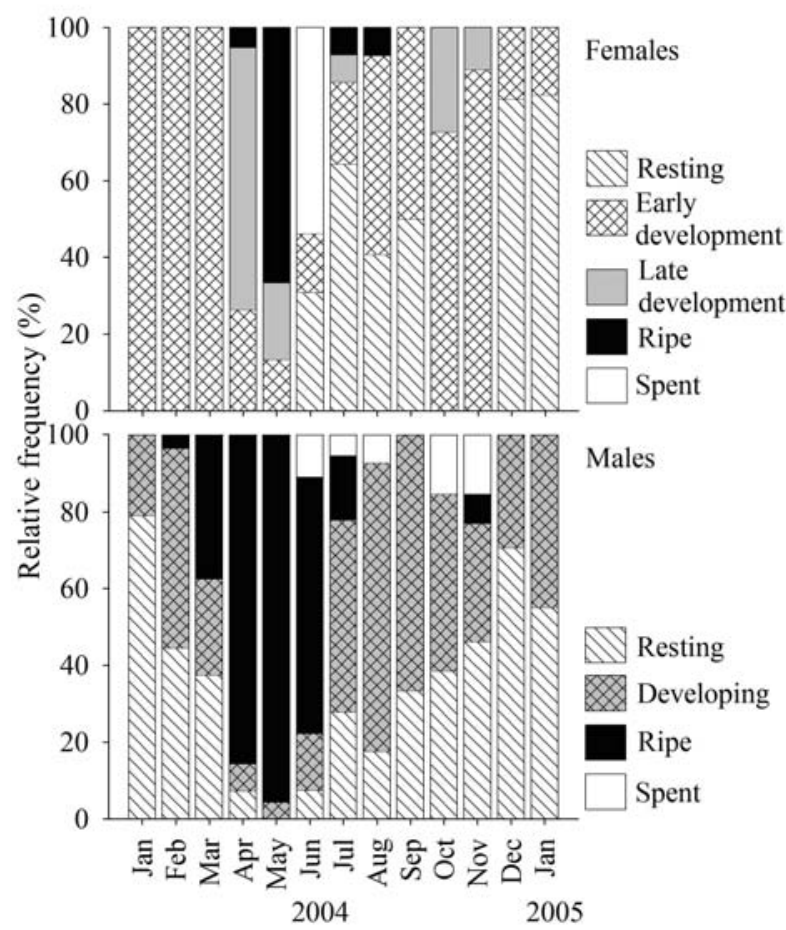

Figure 2

Monthly frequencies of females and males $S$. annulatus gonadal developmental stages

Frecuencias mensuales de las fases de desarrollo gonadal de hembras y machos de $S$. annulatus

The GSI turned out to be a good indicator of gonadal development (Table 3), especially for the ripening phase, which had the significantly higher mean value in both, females (GSI $=10.10, F=195.99$, $P<0.05)$ and males (GSI $=6.72, F=338.76, P<0.05)$. The minimum GSI values were 0.38 and 0.31 in females and males, respectively, corresponding to the resting phase in both cases. On the other hand, GSI displayed a significant seasonal variation (Fig. 3) in both, females $(F=27.10, P<0.05)$ and males $(F=$ 38.33, $P<0.05)$. Both sexes displayed similar trends; however, GSI values were significantly lower in males relative to females $(F=4.01, P=0.046)$. The significantly higher means occurred in May (8.85) for females and in April-May (6.81 and 7.27, respectively) for males.

The Kn showed no significant variations in relation to the gonadal developmental phases (Table 3), neither

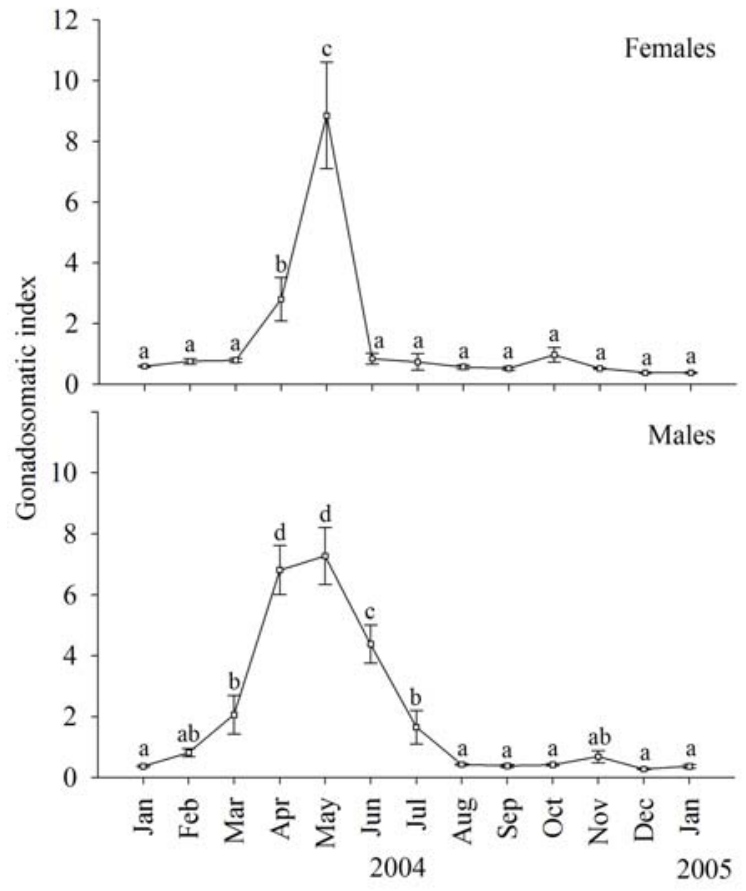

Figure 3

Monthly variation of mean gonadosomatic index values for females and males $S$. annulatus. Data were analyzed by one-way ANOVA followed by Newman-Keuls test. Means not sharing the same superscript are significantly different $(P<0.05)$. Bars correspond to standard error

Variación mensual de los valores medios del índice gonadosomático para hembras y machos de S. annulatus. Los datos fueron analizados mediante ANOVA de una vía seguidos por pruebas de Newman-Keuls. Las medias que no presentan la misma letra son significativamente diferentes

$(P<0,05)$. Las barras corresponden al error estándar

in females $(F=2.97, P>0.05)$ nor in males $(F=1.24$, $P>0.05$ ). Furthermore, the mean $\mathrm{Kn}$ values were equal between females and males $(F=0.01, P>0.05)$ and they varied within a very narrow range (0.48 to 1.56 in females, and from 0.62 to 1.46 in males) (Fig. 4). The Kn showed significantly higher values from November to January 2005 in both, females ( $F=13.57, P<0.05$ ) and males $(F=15.75, P<0.05)$, concurrently with reproductive inactivity. No significant correlation was found between GSI and $\mathrm{Kn}$ in both, females ( $\mathrm{r}=0.06$; $P=0.40 ; \mathrm{n}=222)$ and in males $(\mathrm{r}=0.05 ; P=0.44 ; \mathrm{n}=$ 268). 
Table 3

Mean ( \pm standard error) of gonadosomatic index (GSI) and relative condition factor (Kn) for females and males $S$. annulatus by developmental stage. Within rows, values not sharing the same letter are significantly different

Media ( \pm error estándar) del índice gonadosomático (GSI) y del factor de condición relativo (Kn) para hembras y machos de S. annulatus por fase de desarrollo. Dentro de los renglones, los valores que no muestran la misma letra son significativamente diferentes

\begin{tabular}{|c|c|c|c|c|c|c|}
\hline \multirow[t]{2}{*}{ Sex/Index } & \multirow[t]{2}{*}{ Resting } & \multicolumn{2}{|c|}{ Developing } & \multirow[t]{2}{*}{ Ripe } & \multirow[t]{2}{*}{ Spent } & \multirow[t]{2}{*}{ ANOVA } \\
\hline & & Early & Late & & & \\
\hline Female/GSI & $0.38 \pm 0.02 \mathrm{a}$ & $0.65 \pm 0.03 b$ & $2.59 \pm 0.37 d$ & $10.1 \pm 1.73 \mathrm{e}$ & $1.13 \pm 0.28 \mathrm{c}$ & $P<0.05$ \\
\hline Male/GSI & $0.31 \pm 0.02 \mathrm{a}$ & \multicolumn{2}{|c|}{$0.74 \pm 0.08 b$} & $6.72 \pm 0.44 d$ & $1.12 \pm 0.37 \mathrm{c}$ & $P<0.05$ \\
\hline Female/Kn & $1.05 \pm 0.02$ & $0.98 \pm 0.01$ & $1.02 \pm 0.03$ & $1.08 \pm 0.04$ & $1.10 \pm 0.03$ & $P>0.05$ \\
\hline Male/Kn & $1.02 \pm 0.08$ & \multicolumn{2}{|c|}{$0.99 \pm 0.06$} & $1.02 \pm 0.01$ & $0.96 \pm 0.05$ & $P>0.05$ \\
\hline
\end{tabular}

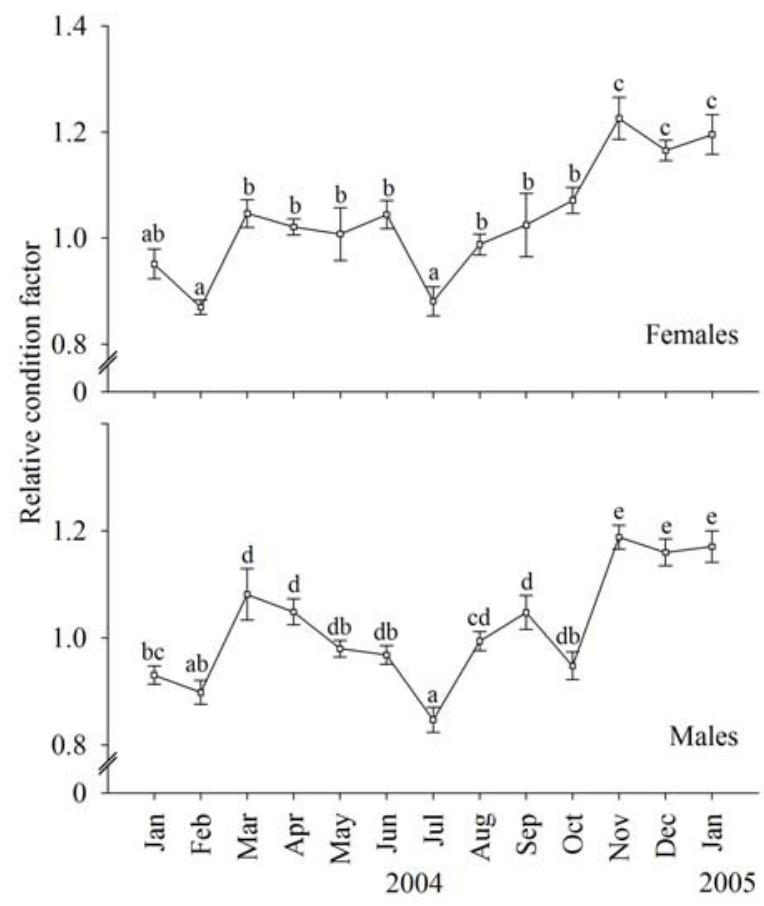

Figure 4

Monthly variation of mean relative condition factor values for females and males $S$. annulatus. Data was analyzed by one-way ANOVA followed by Newman-Keuls test. Means not sharing the same superscript are significantly different $(P<0.05)$. Bars correspond to standard errors

Variación mensual de los valores medios del factor de condición relativo para hembras y machos de $S$. annulatus. Los datos fueron analizados mediante ANOVA de una vía seguidos por pruebas de Newman-Keuls. Las medias que no presentan la misma letra son significativamente diferentes

$(P<0,05)$. Las barras corresponden al error estándar 


\section{Discussion}

Both, the size interval (20.5-44 $\mathrm{cm} \mathrm{L}_{\mathrm{t}}$ and 200-2200 g $\mathrm{M}_{\mathrm{t}}$ ) and the gonad macroscopic analysis, together with the length at first maturity (28-30 $\mathrm{cm} \mathrm{L}_{\mathrm{t}}$ ) reported for $S$. annulatus (Díaz-Guevara et al. ${ }^{1}$ ) indicate that the specimens analyzed were mainly adults. The lack of smaller specimens may be a consequence of selectivity in the fishing gear. However, it was observed that Sphoeroides lobatus was frequently captured within lengths of up to $15 \mathrm{~cm} \mathrm{~L}_{\mathrm{t}}$ the same fishing day and using the same hook size as for $S$. annulatus. Furthermore, catches from four trawling events carried out by trawlers off the coast of Mazatlan were inspected and no $S$. annulatus specimens were found below $20 \mathrm{~cm} \mathrm{~L}$. This indicates that younger organism are distributed in different habitats than older ones. In Mexico, the genus Sphoeroides includes species with a confirmed presence in mixohaline environments (Castro-Aguirre et al. 1999). Other works with $S$. annulatus have reported wider size distributions (9.5$43.5 \mathrm{~cm} \mathrm{~L}_{\mathrm{t}}$ and 12.5-1762.5 $\mathrm{g} \mathrm{M}_{\mathrm{t}}$; 3.1-41.5 $\mathrm{cm} \mathrm{L} \mathrm{L}_{\mathrm{t}}$ and 2.3-1987.3 $\mathrm{g} \mathrm{M} \mathrm{M}_{\mathrm{t}}$ ), and even a bimodal distribution (Castellanos-Rodríguez et al. 1982, Rojas-Mancillas 2004). However, these works included sampling areas within estuaries or lagoon systems, as well as trawling samples. The above suggests that $S$. annulatus shows a differential distribution according to size/age, with juveniles inhabiting mixohaline systems and adults in the neritic zone, although large specimens can occasionally be found in estuarine-lagoon systems at low frequencies (Rojas-Mancillas 2004). Such behavior favors the conservation of this resource, given that it protects juveniles from fishing.

The $\mathrm{L}_{\mathrm{t}}-\mathrm{M}_{\mathrm{t}}$ analysis conducted for males and females pooled, indicates that $S$. annulatus shows a negative allometric growth. This opposes the findings reported by Rojas-Mancillas (2004), i.e. a positive allometric growth in S. annulatus, with a more pronounced growth in terms of mass relative to length. On the other hand, Castellanos-Rodríguez et al. (1982) calculated a slope that resembles the one reported by Rojas-Mancillas (2004) more closely than the one reported here. This difference however, may be attributed to the narrow

\footnotetext{
${ }^{1}$ Díaz-Guevara R, BP Ceballos-Vazquez \& M Arellano-Martínez. 2005. Biología reproductiva del botete diana Sphoeroides annulatus (Pisces: Tetraodontidae) en la bahía de La Paz, B. C. S. México. X Congreso de la Asociación de Investigadores del Mar de Cortés, A.C. y IV Simposium Internacional sobre el Mar de Cortés, FACIMARUAS, Mazatlán, Sinaloa.
}

size interval used in the present study. On the other hand, the analysis by sex revealed statistical evidences that males display an isometric growth, whereas growth in $S$. annulatus adult females is negative allometric, i.e. they grow more markedly in length than in mass. A likely explanation is that the energy expenditure demanded by females for gamete production results in a lower amount of energy available for mass growth compared to males.

This work proposes a morpho-chromatic scale including five gonadal development phases for females and four for males. Other works have proposed six - or seven-phase scales for S. annulatus, S. testudineus and S. greeleyi (Castellanos-Rodríguez et al. 1982, Rocha et al. 2002, Schultz et al. 2002). However, subjectivity increases with wider scales. The application of the morpho-chromatic scale proposed here in combination with GSI (which confers some rigorousness to the method) turned out to be an acceptable method to have an approximation on the species' reproductive season. Nevertheless, the use of GSI as an indicator of reproductive condition at an individual level must be managed with caution, since no significant differences were found in GSI values between other development phases (i.e. resting phase and early developing in females, and developing and spent in males). Additionally, the highest mean GSI value (10.10) in females is very similar to that of fishes from temperate latitudes (10-25\% of total mass) (García-Cagide et al. 1994).

On the other hand, the morpho-chromatic analysis showed that $S$. annulatus testes ripen earlier than ovaries, although in a low proportion, suggesting that males are potentially reproductive for a wider period. This may be due to that the testis is smaller than the ovary, sperm requires no accumulation of yolk and, hence, males require less energy expenditure for ripening. For this reason, ripening in males can potentially start earlier than in females, thereby ensuring synchronous spawning. A similar condition has been reported for both, freshwater (Encina \& Granado-Lorencio 1997) and marine fishes (ArellanoMartínez \& Ceballos-Vázquez 2001). Both the qualitative (morpho-chromatic) and the quantitative (GSI) analyses reveal that the reproductive cycle of $S$. annulatus in Mazatlan bay is clearly seasonal, with the main reproductive activity period from April to August, coinciding with the rise in water temperature, plus a shorter, less intense period, in October-November, 
when water temperature starts to fall. Although information on the reproductive season of $S$. annulatus is scarce, the data available coincide with the major reproductive period reported in this work. For an area near Mazatlan, Castellanos-Rodríguez et al. (1982) reported the reproductive season of $S$. annulatus for May-June. In Bahía de La Paz, Southern Baja California, Mexico, Díaz-Guevara et al. ${ }^{1}$ reported that reproduction takes place from May to September. For other species from different areas, the reproductive season occurs at different times of the year; from September to January for S. testudineus (Rocha et al. 2002) and from October to January for S. greeleyi (Schultz et al. 2002), which are due to the speciesspecific characteristics related to the study area's environmental conditions.

Usually, Kn is negatively correlated to GSI (degree of ripening; Maddock \& Burton 1999), thereby reflecting somatic energy transfer to gonads to support gametogenesis (González \& Oyarzún 2002). Such correlation was not found in this work. Nevertheless, Kn shows a trend towards a significant decrease $(P<$ 0.05) during the reproductive activity period (March in comparison with July), besides showing significantly higher values during the reproductive inactivity period (November-January 2005).

The sex ratio has a specific adaptive nature in relation to reproduction; the variations in reproductive activity observed through samplings frequently depend on differences in the habitat of each sex, which may vary throughout the annual cycle or during ontogeny (García-Cagide et al. 1994). According to our findings, the sex ratio in $S$. annulatus was statistically 1:1, similar to the $1 \mathrm{M}: 1.2 \mathrm{~F}$ ratio reported by CastellanosRodríguez et al. (1982) for this same species. However, the monthly analysis revealed that the sex ratio differed significantly (1M:0.48F) in June, coinciding with the reproductive season. Temporal variations in sex ratio have also been observed in $S$. testudineus (Rocha et al. 2002) and S. greeleyi (Schultz et al. 2002).

\section{Acknowledgments}

The authors deeply thank the Playa Norte's fishermen for committing efforts to attain this investigation's objective. We are also thankful to A. Inzunza, J.M. Sánchez, L.A. Salcido, A. Sánchez and V. Ríos for their support during sampling. We are grateful to the Secretaría de Investigación y Postgrado at the Instituto
Politécnico Nacional for funding this work (project SIP20050987). We acknowledge the fellowships granted by the Programa Institutional de Formación de Investigadores and CONACyT to R. SánchezCárdenas, and we thank the Comisión de Operación y Fomento de Actividades Académicas and EDI for the fellowships granted to M. Arellano-Martínez and B.P. Ceballos-Vázquez. A special acknowledgment to the anonymous reviewers for their comments to improve this work. Thanks to María Elena Sánchez-Salazar, M. Sc., for her editorial contribution to the English manuscript.

\section{Literature cited}

Abdo de la Parra MI \& N Duncan. 2002. Avances en el cultivo experimental del botete diana (Sphoeroides annulatus). Panorama Acuícola 7(2): 42-43.

Agger P, O. Bagge, O Hansen, E Hoffman, MJ Holden, GL Kesteven, H Knudsen, DFS Raitt, A Saville \& T Williams. 1974. Manual de ciencia pesquera: Parte 2Métodos para investigar los recursos y su aplicación. FAO Documentos Técnicos Pesca, T 115 Rev.1: 1-255.

Ahasan HAMN, AA Mamun, SR Karim, MA Bakar, EA Gazi \& CS Bala. 2004. Paralytic complications of puffer fish (Tetrodotoxin) poisoning. Singapore Medical Journal 45(2): 73-74.

Álvarez-Cadena J, NR Cortés-Altamirano \& GA MussotPérez. 1987. Composición y abundancia de las larvas de peces en el sistema lagunar Huizache-Caimanero, Parte II Tapo Botadero. Anales del Instituto de Ciencias del Mar y Limnología UNAM 15: 143-157.

Arellano-Martínez M \& BP Ceballos-Vázquez. 2001. Reproductive activity and condition index of Holacanthus passer (Teleostei: Pomacanthidae) in the Gulf of California, México. Revista de Biología Tropical 49: 939943.

Castellanos-Rodríguez S, JL García-Rendón, JL Guevara-Osuna \& FC Franco-Aramburo. 1982. Aportación al conocimiento de la especie Sphoeroides annulatus (Jenyns). Tesis profesional, Facultad de Ciencias del Mar, Universidad Autónoma de Sinaloa, México, 62 pp.

Castro-Aguirre JL, H Espinoza-Pérez \& JJ SchmitterSoto. 1999. Ictiofauna estuarina, lagunar y vicaria de México, 711 pp. Limusa, México.

DeVlaming V, G Grossman \& F Chapman. 1982. On the use of the gonadosomatic index. Comparative Biochemical Physiology 73A(1): 31-39. 
Encina L \& C Granado-Lorencio. 1997. Seasonal variations in the physiological status and energy content of somatic and reproductive tissues of chub. Journal of Fish Biology 50: 511-522.

García-Cagide A, R Claro \& BV Koshelev. 1994. Reproducción. En: Claro R (ed), Ecología de los peces marinos de Cuba, 525 pp. Centro de Investigaciones Biológicas de Quintana Roo, México.

González P \& C Oyarzún. 2002. Biological index variability in Pinguipes chilensis Valenciennes, 1833 (Perciformes, Pinguipedidae): Are they correlated? Gayana 66(2): 249253.

Ghosh S, AK Hazra, S Banerjee \& B Mukherjee. 2005. Ecological monitoring for ascertaining the bio-safety of liver lipids from some Indian marine puffer fishes. Fishery Science 71: 29-37.

Le Cren ED. 1951. The length-weight relationships and seasonal cycle in gonad weight and condition in perch (Perca fluviatilis). Journal of Animal Ecology 20: 201219.

Maddock DM \& MPM Burton. 1999. Gross and histological observations of ovarian development and related condition changes in America plaice. Journal of Fish Biology 53: 928-944.

Mariscal-Romero J, B Aguilar-Palomino, G LucanoRamírez, AR Raymundo-Huizar, LE RodríguezIbarra, S Ruiz-Ramírez \& G González-Sansón. 1998. Asociaciones de peces demersales de la plataforma continental de Colima y Jalisco, México (Primavera 1995). Ciencias Marinas 24(1): 35-54.

Ocampo-Peraza D. 1983. El botete (Sphoeroides annulatus), características y origen como alimento humano. Revista de Ciencias del Mar 5: 9-11.

Ochoa JL, EJ Núñez-Vázquez, A García-Ortega \& I Abdo de la Parra. 2006. Food safety: study about the toxicity of the cultivated bullseye puffer fish (Sphoeroides annulatus, Jenyns, 1843). Panorama Acuícola Magazine 11(4): 22-27.

Rocha C, LF Favaro \& HL Spach. 2002. Biología reproductiva de Sphoeroides testudineus (Linneus) (Pisces, Osteichthyes, Tetraodontidae) da gamboa do Banguaçu, Baía de Paranaguá, Paraná, Brasil. Revista Brasileira de Zoologia 19(1): 57-63.

Rojas-Macillas TA. 2004. Distribución de Sphoeroides annulatus (Jenyns, 1842), y S. lobatus (Steindachner, 1870), con relación a factores abióticos en el sistema lagunar de Santa María La Reforma, Sinaloa. Tesis profesional, Facultad de Ciencias del Mar, Universidad Autónoma de Sinaloa, México, 47 pp.

Schultz YD, LF Favaro \& HL Spach. 2002. Aspectos reproductivos de Sphoeroides greeleyi (Gilbert), Pisces, Osteichthyes, Tetraodontidae, da gamboa do Baguaçu, Baia de Paranaguá, Paraná, Brasil. Revista Brasileira de Zoologia 19(1): 65-76.

Zar JH. 1996. Biostatistical analysis, 121 pp. Prentice Hall, New Jersey.

Recibido el 7 de mayo de 2007 y aceptado el 31 de agosto de 2007 